\title{
Here's Why U.S. Manufacturing Is Fundamentally Strong
}

Kevin L. Kliesen, Business Economist and Research Officer

John A. Tatom, Fellow, Institute for Applied Economics, Global Health and the Study of Business Enterprise, The Johns Hopkins University

ccording to a recent Gallup poll, ${ }^{1}$ Americans believe a vibrant manufacturing sector is "key" to boosting job growth. Yet, U.S. manufacturing employment has declined over time and even more so during the Great Recession. Moreover, the growth of manufacturing output and productivity, which has historically outpaced the overall economy, has also weakened relatively more over the past several years. Given these conditions and growing U.S. trade deficits, many believe that U.S. manufacturing is in a downward spiral and can no longer compete globally. We believe that U.S. manufacturing is fundamentally strong and that claims about foreign competition tend to be overstated. Let's dig deeper than the headlines and show why we don't believe the hype about the death of U.S. manufacturing. ${ }^{2}$

Of course, aspects of U.S. manufacturing have declined since its heyday, and recent declines have been prominent. For example, between December 2007 (the previous business cycle peak) and March 2010, the number of employees in the manufacturing sector declined from almost 13.75 million to about 11.5 million-the lowest level since March 1941. However, manufacturing output has increased since the trough of the Great Recession, though its growth (like that of the overall U.S. economy) has been unusually weak. ${ }^{3}$ During the recent recovery, manufacturing output has increased at just a 2.2 percent annual rate, slower than the 3 percent average rate after the 2001 recession and much slower than the 5 percent average rate for the two expansions in the 1980s and 1990s. ${ }^{4}$ But there's more to examine before drawing any conclusions.

\section{U.S. Manufacturing in the Global Arena}

One way to measure the competitiveness of U.S. manufacturing is to compare its growth with the growth in other countries. If other countries have healthier manufacturing sectors, that might be evidence of a decline in U.S. performance.

The United States and seven other developed countries make up about 82 percent of $\mathrm{OECD}^{5}$ manufacturing activity:
Those countries are France, Germany, Italy, Japan, Mexico, South Korea, and the United Kingdom. In 1997, the real manufacturing output of all eight countries was $\$ 3.97$ trillion. U.S. output was a little more than a third of this total, with Japan accounting for a little more than a quarter. Germany provided 14 percent, followed by Italy's nearly 8 percent. The other countries were less than 6 percent each.

U.S. manufacturing's slump is largely due to the poor performance of the overall economy.

By 2015, the U.S. share had risen to about 36 percent. The shares of Mexico and South Korea had risen slightly and Germany's share hadn't changed much. All other OECD countries saw their share of manufacturing output decline, with Japan's share declining nearly 3 percentage points. By this standard, U.S. manufacturing is competing well against the manufacturing sectors of other large, developed countries.

But then there's China, which isn't included in the OECD. According to statistics from the World Bank, ${ }^{6}$ China surpassed the United States in 2014 as the world's largest manufacturing country in value-added terms. By 2015 , China's real manufacturing output totaled $\$ 4.18$ trillion, considerably more than the $\$ 3.25$ trillion in U.S. output. ${ }^{7}$

From 2005 to 2015, China's share of the world's manufacturing output rose by 10.1 percentage points to 19.7 percent, while the U.S. share fell by 3.5 percentage points to 15.3 percent. Undoubtedly, Chinese manufacturing has gained market share from U.S. manufacturing. But it is also true that China has gained more manufacturing share from other countries. For example, from 2005 to 2015, Japan's share of world manufacturing output declined from 10 percent to 7.9 percent, and the euro area's share declined from 17.7 percent to 13.9 percent. So, while China successfully expanded its market share compared with the United 
Figure 1

Non-Chinese Goods Imports (c.i.f.) as a Percent of U.S. Goods Imports

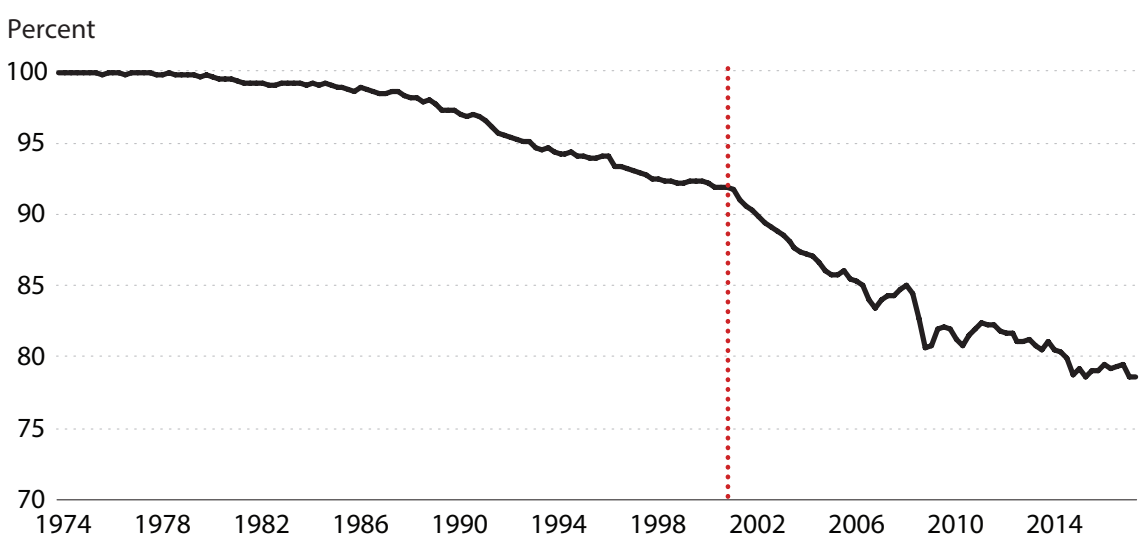

NOTE: Data are SAAR

SOURCE: Authors' calculations based on U.S. Census Bureau data.

Figure 2

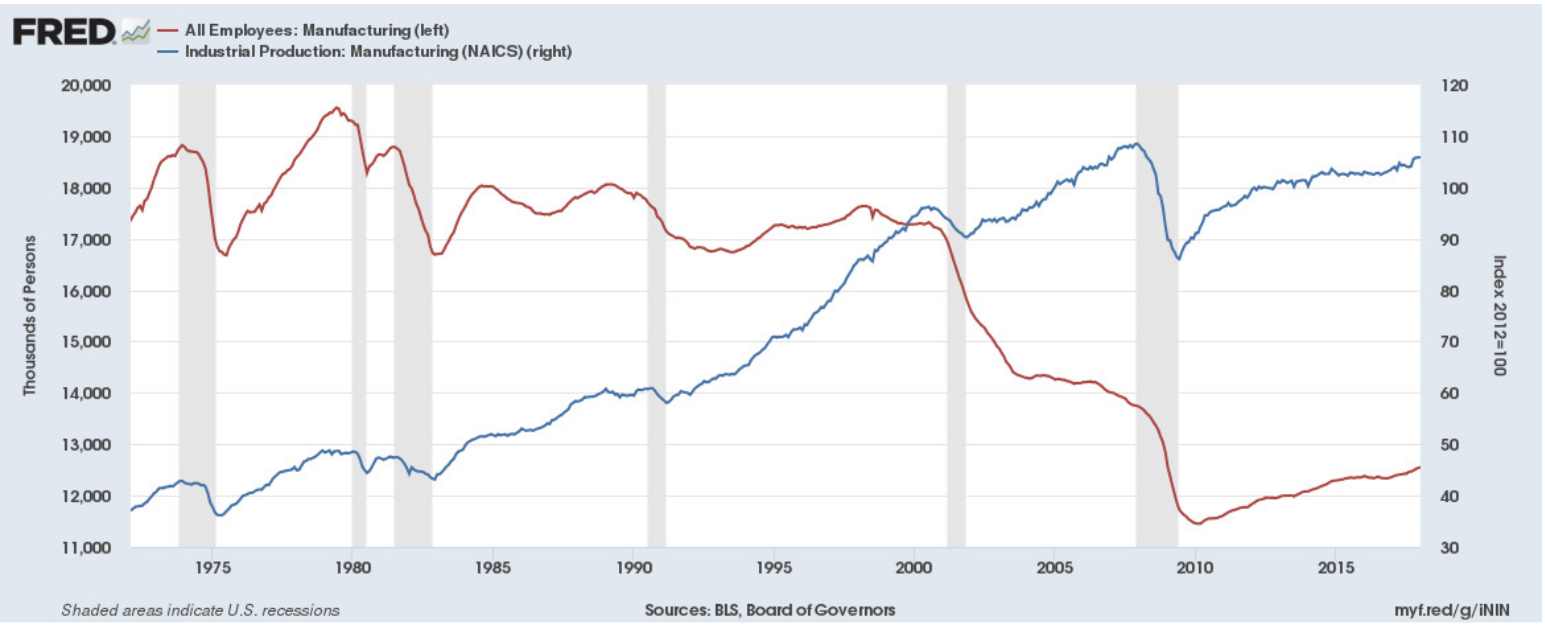

States, that success registered even more at the expense of China's non-U.S. competitors. ${ }^{8}$ For example, as seen in Figure 1, the share of U.S. goods imports from all other countries began to decline rapidly after China's entry into the World Trade Organization in 2001.

Let's also remember our history and look back to Japan's ascent from the ashes of World War II to its status as a manufacturing powerhouse. Claims were made back then, during the 1970s, 1980s, and 1990s, that the surge in Japanese manufacturing would lead to the demise of U.S. manufacturing-claims that now, in hindsight, were overwrought. ${ }^{9}$

And one more note about global competition: It may seem obvious that more imported manufactured goods leads to less U.S. manufactured goods. But, contrary to this popular opinion, imports do not crowd out aggregate domestic production. Instead, there is a strong positive relationship between imports and manufacturing output and employment. Many imports are intermediate materials and capital goods that, in fact, not only are essential to domestic production but also increase the productivity of U.S. manufacturers who produce goods that are exported. ${ }^{10}$

\section{The Manufacturing Sector Is Especially Susceptible to Negative Economic Conditions}

U.S. manufacturing is growing and has a large global share; but, as we've noted here, it has declined relative to its earlier performance-especially its productivity and output growth.

Figure 2 plots domestic manufacturing output and employment over the past 45 years, with the shaded areas representing recessions. It's clear that manufacturing output and employment are very sensitive to the state of the economy. ${ }^{11}$ In fact, the National Bureau of Economic 
Research Business Cycle Dating Committee uses industrial production as a metric when dating business cycle peaks and troughs. Manufacturing output fell by 20 percent from the fourth quarter of 2007 to the second quarter of 2009,12 which was the largest recession-induced decline since the 1930s. In percentage terms, manufacturing employment fell by 13.7 percent, or about 1.9 million jobs. ${ }^{12} \mathrm{We}$ don't see this as a signal that U.S. manufacturing is weak, however; instead, we see economy-wide factors at work.

Slow growth of the U.S. population in general, and specifically of the labor force, has slowed long-term U.S. economic growth and employment. ${ }^{13}$ This overall slow growth has reduced the demand for capital goods, indirectly impeded the pace of innovation, and further reduced the pace of potential output growth. Slower long-term economic growth reduces the growth of demand for output generally and manufacturing output and employment especially.

And demand for manufactured durable goods is even more sensitive to short-term fluctuations in income, as we've seen in the recent recession. So, along with the aggregate economy, manufacturing output and productivity growth have been unusually slow.

A bit more on the reference above to innovation and its effects on the aggregate economy: The pace of technological change embodied in labor productivity has been dismal, in part compounding the effect of weak capital formation. And Decker et al. (2014) show that economic dynamism - what one could characterize as entrepreneurship, reflected, for example, in the share of new firms and start-ups-has declined for the past 30 years and that this decline accelerated after 2000, along with comparable trends in new patents. Phelps (2013) argues that innovation creates economic dynamism, which in his view is a prerequisite for high growth, but it has been in decline for a long time. Although researchers continue to debate and study the issue, high taxes, regulations, and less-competitive markets have tended to slow the pace of innovation and thus economic growth.

\section{How Can We Secure a Brighter Future for Manufacturing?}

We've described the current state of U.S. manufacturing, but let's consider its performance over time. Manufacturing has historically experienced rapidly rising productivity growth and declining employment. However, this has not resulted in a smaller share of manufacturing output relative to GDP. In fact, manufacturing output has been a roughly constant share of GDP over time. This has been evident in the historically falling relative price of manufacturing output. Rising levels of productivity benefit manufacturing (as with other sectors), but also naturally lead to declining employment-much as the agricultural sector has experienced declining employment and rising output in the twentieth century. ${ }^{14}$ Hence, some declines in employment are to be expected.

But in contrast with historical trends, and probably counter to the expectations of many economists, manufacturing has not enjoyed strong output growth over the past few years. As noted earlier, slowing output growth has a slowing labor component. But slowing output growth also reflects weaker manufacturing productivity growth, which slowed more sharply after the business cycle peak at the end of 2007-both absolutely and relative to aggregate U.S. productivity growth. It even began to fall in 2011-14. From the last business cycle peak at the end of 2007 to the third quarter of 2017, manufacturing output per worker has risen at only a 0.6 percent rate, slower than the real GDP per worker growth rate of 0.9 percent. Thus, weaker manufacturing output growth importantly reflects fundamentals in the aggregate economy.

So, if there's any credence to the view that U.S. manufacturing has diminished, it mostly stems from the nation's slower economic growth process and very weak economic recovery. If aggregate productivity rebounds, it will be reflected in a re-energized manufacturing sector. Of course, this slowdown in overall productivity and output growth may be permanent. Gordon (2016) argues this point. But Mokyr (2002), Branstetter and Sichel (2017), and others argue that this slowdown is transitory and can be reversed. ${ }^{15}$.

\section{Notes}

1 See http://news.gallup.com/poll/211010/americans-manufacturing-key-job-creation.aspx.

2 This essay is a revised version of Kliesen and Tatom (2018). For more details, see the original article and the references therein. We thank Brian Levine for excellent research assistance. We also thank George Fortier for his assistance in the preparation of this essay.

${ }^{3}$ Bordo and Haubrich (2012) have pointed to the unusually weak recovery from the Financial Crisis.

4 Strauss (2003) points out that manufacturing performance can't be judged solely by declining employment during and after the 2001 recession; the recovery in output was driven by continuing rapid productivity growth, the mainstay of strong manufacturing performance.

5 According to the World Bank, the 35 Organisation for Economic Co-operation and Development (OECD) countries made up about 53 percent of total global manufacturing value-added in 2015 (the most-current year available).

6 World Bank data are measured in constant 2010 dollars: https://data.worldbank.org/indicator/NV.IND.TOTL.KD.

${ }^{7}$ As stressed by Owyang and Shell (2017), China's data should be handled carefully.

8 We find some evidence that China's entry into the World Trade Organization in December 2001 was associated with declines in U.S. manufacturing employ- 
ment, as others have found, but the effect is weak; the surge in Chinese imports doesn't appear to be a dominant factor behind trends in U.S. manufacturing employment since the early 2000s. See Kliesen and Tatom (2018) for a moredetailed analysis.

9 See Thurow (1993).

10 Se Kliesen and Tatom (2013) for a more-detailed analysis.

11 From the first quarter of 1973 to the third quarter of 2017, the correlation coefficient between four-quarter growth rates in manufacturing output and real GDP was 0.87 ; it was 0.89 between manufacturing employment and civilian employment.

12 The trough in manufacturing employment occurred later, in the first quarter of 2010. Manufacturing employment declined by 16.3 percent, or 2.3 million jobs, from the fourth quarter of 2007 to the first quarter of 2010 .

13 See Fernald et al. (2017).

14 Again, see Fernald et al. (2017) for a useful review of most of these issues from a more aggregate approach that focuses especially on the weakness of the recent recovery.

15 Policy initiatives at the federal level can help improve, or impair, aggregate economic growth and thus the performance of the manufacturing sector. For more discussion on this issue, see Kliesen and Tatom (2018).

\section{REFERENCES}

Barro, Robert J., Michael J. Boskin, John Cogan, Douglas Holtz-Eakin, Glenn Hubbard, Lawrence B. Lindsey, Harvey S. Rosen, George P. Schultz, and John B. Taylor. "How Tax Reform Will Lift the Economy." The Wall Street Journal, November 25, 2017; https://www.wsj.com/articles/how-tax-reform-will-liftthe-economy-1511729894?mg=prod/accounts-wsj.

Bordo, Michael D. and Joseph G Haubrich. "Deep Recessions, Fast Recoveries, and Financial Crises: Evidence from the American Record." Federal Reserve Bank of Cleveland Working Paper No. 12-14, June, 2012.

Branstetter, Lee, and Daniel Sichel. "The Case for an American Productivity Revival." Peterson Institute for International Economics, Policy Brief 2017, pp. 17-26.

Decker, Ryan, John Haltiwanger, Ron Jarmin, and Javier Miranda. "The Role of Entrepreneurship in U.S. Job Creation and Economic Dynamism." Journal of Economic Perspectives, 2014, 28(3), pp. 2-24; https://doi.org/10.1257/jep.28.3.3.

Fernald, John G., Robert E. Hall, James H. Stock, and Mark W. Watson. “The Disappointing Recovery of Output After 2009." Brookings Papers on Economic Activity, Spring 2017, (1), pp. 1-58; https://doi.org/10.1353/eca.2017.0000.

Gordon, Robert J. The Rise and Fall of American Growth: The U.S. Standard of Living Since the Civil War. Princeton: Princeton University Press, 2016; https://doi.org/10.1515/9781400873302.

Kliesen, Kevin L. and John A. Tatom. “U.S. Manufacturing and the Importance of International Trade: It's Not What You Think. Federal Reserve Bank of St. Louis Review, 2013, 95(1), pp. 27-49.

Kliesen, Kevin L. and John A. Tatom. "Is American Manufacturing in Decline?" Business Economics, forthcoming, 2018.

Mokyr, Joel. The Gifts of Athena: Historical Origins of the Knowledge Economy. Princeton and Oxford: Princeton University Press, 2002.

Owyang, Michael T., and Hannah G. Shell. "China's Economic Data: An Accurate Reflection, or Just Smoke and Mirrors?" Federal Reserve Bank of St. Louis Regional Economist, 2017, (2), pp. 7-12.

Phelps, Edmund. Mass Flourishing: How Grassroots Innovations Created Jobs, Challenge, and Change. Princeton: Princeton University Press, 2013; https://doi.org/10.1515/9781400848294.

Strauss, William. "The Disappearance of Manufacturing," Federal Reserve Bank of Chicago, No. 190, June 2003.

Thurow, Lester. Head to Head: The Coming Economic Battle Among Japan, Europe, and America. New York: Warner Books, 1993. 